\title{
Dual Function of Wnt Signaling during Neuronal Differentiation of Mouse Embryonic Stem Cells
}

\author{
Hanjun Kim, ${ }^{1,2}$ Sewoon Kim, ${ }^{1}$ Yonghee Song, ${ }^{1}$ Wantae Kim, ${ }^{1}$ \\ Qi-Long Ying, ${ }^{2}$ and Eek-hoon Jho ${ }^{1}$ \\ ${ }^{1}$ Department of Life Science, University of Seoul, 163 Seoulsiripdaero, Dongdaemun-gu, Seoul 130-743, Republic of Korea \\ ${ }^{2}$ Eli and Edythe Broad Center for Regenerative Medicine and Stem Cell Research at USC, Keck School of Medicine, \\ University of Southern California, Los Angeles, CA 90033, USA
}

Correspondence should be addressed to Qi-Long Ying; qying@usc.edu and Eek-hoon Jho; ej70@uos.ac.kr

Received 19 February 2015; Accepted 24 March 2015

Academic Editor: Laura Lasagni

Copyright (C) 2015 Hanjun Kim et al. This is an open access article distributed under the Creative Commons Attribution License, which permits unrestricted use, distribution, and reproduction in any medium, provided the original work is properly cited.

\begin{abstract}
Activation of Wnt signaling enhances self-renewal of mouse embryonic and neural stem/progenitor cells. In contrast, undifferentiated ES cells show a very low level of endogenous Wnt signaling, and ectopic activation of Wnt signaling has been shown to block neuronal differentiation. Therefore, it remains unclear whether or not endogenous $\mathrm{Wnt} / \beta$-catenin signaling is necessary for selfrenewal or neuronal differentiation of ES cells. To investigate this, we examined the expression profiles of Wnt signaling components. Expression levels of Wnts known to induce $\beta$-catenin were very low in undifferentiated ES cells. Stable ES cell lines which can monitor endogenous activity of Wnt/ $\beta$-catenin signaling suggest that Wnt signaling was very low in undifferentiated ES cells, whereas it increased during embryonic body formation or neuronal differentiation. Interestingly, application of small molecules which can positively (BIO, GSK3 $\beta$ inhibitor) or negatively (IWR-1-endo, Axin stabilizer) control Wnt/ $\beta$-catenin signaling suggests that activation of that signaling at different time periods had differential effects on neuronal differentiation of $46 \mathrm{C} \mathrm{ES} \mathrm{cells.} \mathrm{Further,}$ ChIP analysis suggested that $\beta$-catenin/TCF1 complex directly regulated the expression of Sox1 during neuronal differentiation. Overall, our data suggest that Wnt/ $\beta$-catenin signaling plays differential roles at different time points of neuronal differentiation.
\end{abstract}

\section{Introduction}

Embryonic stem (ES) cells are pluripotent and self-renewing cells derived from the inner cell mass of preimplantation blastocysts. These cells can differentiate into the following three germ layers: the ectoderm, mesoderm, and endoderm. Due to these characteristics, ES cells are considered useful tools in both research and regenerative medicine. Therefore, it is important to understand how stem cells maintain their selfrenewal capacity and differentiate into each specific lineage [1-3]. However, the molecular mechanisms of ES cell selfrenewal and differentiation remain poorly understood.

ES cells can be differentiated into neuronal cell lineage in vitro. Generally, for differentiation into neuronal cells, ES cells are aggregated to form embryoid bodies (EBs) in suspension culture for 4 days and treated with retinoic acid (RA) [4]. However, it is difficult to manipulate a specific lineage as RA treatment has been shown to induce other cell lineages.
To avoid these problems, a chemically defined medium for neuronal differentiation was developed $[5,6]$. Using N2B27 medium, 46C cells (mouse ES cells containing Sox1 promoter-driven EGFP) can be reproducibly differentiated into a neuronal lineage without $\mathrm{EB}$ formation or treatment with RA, and thereby it has been used to examine the effects of gene manipulation such as depletion or ectopic expression on neuronal differentiation $[5,6]$.

Wnts are secreted signaling proteins that regulate a variety of developmental processes, including cell growth, motility, and differentiation [7]. Wnt $/ \beta$-catenin signaling is conserved in worms, flies, fish, frogs, mice, and humans [8]. In the absence of Wnt, $\beta$-catenin forms a "destruction complex" along with the scaffold protein Axin, the tumor suppressor gene product APC, and GSK- $3 \beta$ that is phosphorylated by casein kinases (CK1) and glycogen synthase kinase $3 \beta$ (GSK$3 \beta$ ). Phosphorylation of $\beta$-catenin triggers its ubiquitination by $\beta$-TrCP, followed by proteasomal degradation $[9,10]$. 
However, when Wnt binds to its receptor Frizzled and coreceptor LRP5/6, the cytoplasmic component dishevelled blocks $\beta$-catenin degradation, leading to the accumulation of $\beta$-catenin in the cytoplasm. Stabilized $\beta$-catenin then enters the nucleus where it interacts with TCF/LEF [11-13] and activates the expression of target genes such as $C-M y c$, Cyclin D1, Brachury, and Twin.

Wnt/ $\beta$-catenin signaling has been shown to play important roles in ES cell self-renewal and differentiation [14-17]. Activation of $\mathrm{Wnt} / \beta$-catenin signaling prevents differentiation of human and mouse ES cells. For example, activation of Wnt signaling by GSK3 $\beta$ inhibitor maintains self-renewal of human and mouse ES cells, and Wnt/ $\beta$-catenin signaling upregulates Stat 3 activity and prevents differentiation of mouse ES cells [18, 19]. Furthermore, TCF3, a terminal transcription factor in Wnt signaling, represses Nanog and delays differentiation of ES cells [20]. However, other evidence has shown that activation of $\mathrm{Wnt} / \beta$-catenin signaling by Wnt3a recombinants induces cell differentiation as well as proliferation [21]. Wnt/ $\beta$-catenin signaling is also involved in regulating the neuronal differentiation of ES cells [22]. On the other hand, it has been shown that the Wnt antagonist sFRP2 induces neuronal differentiation [23]. Therefore, the roles of endogenous Wnt/ $\beta$-catenin signaling and its components in the self-renewal and neuronal differentiation of ES cells remain controversial.

In this study, we examined the endogenous level of $\mathrm{Wnt} / \beta$-catenin signaling components during neuronal differentiation. The data using reporter ES cell lines representing endogenous $\mathrm{Wnt} / \beta$-catenin signaling activity showed that Wnt $/ \beta$-catenin signaling increased during neuronal differentiation. Interestingly, $\mathrm{Wnt} / \beta$-catenin signaling increased until formation of neuronal precursor cells; however, it was reduced during later periods of neuronal differentiation. Differential regulation of neuronal differentiation by the treatment of activator or inhibitor of Wnt/ $\beta$-catenin signaling suggested that Wnt signaling plays dual roles during neuronal differentiation.

\section{Materials and Methods}

2.1. Cell Culture. E14 and 46C ES cells (ES cell line in which EGFP is substituted into the ORF of the Soxl gene, a reporter for differentiation into neural precursor cells) were cultured in mouse ES (mES) cell medium (DMEM (Gibco) supplemented with 15\% FBS, 2 mM GlutaMAX (Gibco), MEM nonessential amino acids, $\beta$-mercaptoethanol (Gibco), tylosin, and 1\% Pen/Strep (Gibco)) supplemented with LIF (ESGRO, Chemicon) on $0.2 \%$ gelatin-coated dishes. Cells were maintained at $37^{\circ} \mathrm{C}$ in a humidified atmosphere of $5 \%$ $\mathrm{CO}_{2}$.

2.2. Neuronal Differentiation. To induce neuronal differentiation, undifferentiated 46C ES cells were trypsinized and neutralized with serum-containing medium. ES cells were dissociated in N2B27 medium (DMEM/F12 (Gibco), Neurobasal medium (Gibco), N2 supplement (Invitrogen), B27 supplement (Invitrogen), $1 \mathrm{mM}$ GlutaMAX (Gibco),
0.1 M $\beta$-mercaptoethanol (Gibco), and 1\% Pen/Strep (Gibco)) and then plated on a $0.2 \%$ gelatin-coated tissue culture dish (Falcon) containing DMSO (SIGMA), $0.75 \mu \mathrm{M}$ MeBIO (Calbiochem), $0.75 \mu \mathrm{M}$ BIO (Calbiochem) [24], and $0.75 \mu \mathrm{M}$ IWR-1-endo (kindly provided by Dr. Lawrence Lum, University of Texas, Southwestern Medical Center) [25]. N2B27 medium was changed every other day. On the 6th day, EGFPpositive cells (Soxl positive cells) were observed by using a fluorescent microscope (Leica DMIRB, Leica Microsystems). For production of neurons, Soxl-positive cells were replated on PDL-laminin-coated wells in N2B27 medium containing EGF and FGF-2. N2B27 medium was changed every 3-4 days [6].

2.3. FACS Analysis. To analyze 46C ES cell-derived Sox1GFP-positive neural precursors, $46 \mathrm{C}$ cells were differentiated for 6 days in N2B27 medium with MeBIO or BIO and DMSO or IWR. The cells were then trypsinized and neutralized with serum containing medium. After centrifugation, cells were washed two times with PBS and resuspended in PBS. Resuspended cells were analyzed using a FACScan. For data analysis, FACSDiva software was used.

2.4. Transfection and Luciferase Assay. Oct4 promoterEGFP ES cells were stably transfected with TOP-mCherry and Axin2-promoter-mCherry using Amaxa nucleofector according to the manufacturer's instructions. Stably transfected clones were selected in media containing $800 \mu \mathrm{g} / \mathrm{mL}$ of G418 (Gibco).

To measure Wnt signaling activity, pTOP-Flash plasmid and pRL-TK plasmid were transfected into mES cells. Transfected ES cells were cultured in the presence or absence of LIF for $48 \mathrm{~h}$. To measure Soxl promoter activity under nondifferentiation and neuronal differentiation conditions, pGL3-mSoxl promoter plasmid and pRL-TK plasmid were transfected into $46 \mathrm{C}$ cells, which were cultured in $\mathrm{mES}$ medium or N2B27 medium with or without $0.75 \mu \mathrm{M}$ BIO (Calbiochem). Luciferase activity was measured by DualLuciferase reporter assay (Promega).

2.5. Reverse Transcriptase-PCR. Examination of gene expression during neuronal differentiation was carried out by RT-PCR. Total RNA was isolated using TRIzol reagent (Invitrogen) according to the manufacturer's protocol. cDNA was synthesized from total RNA $(1 \mu \mathrm{g})$ in a total reaction volume of $20 \mu \mathrm{L}$ using ImProm-II Reverse Transcriptase (Promega) with random primers. cDNA was amplified under the following conditions: $94^{\circ} \mathrm{C}$ for $2 \mathrm{~min}$, followed by 20,25 , or 30 cycles of $94^{\circ} \mathrm{C}$ for $45 \mathrm{~s}, 58^{\circ} \mathrm{C}$ for $45 \mathrm{~s}$, and $72^{\circ} \mathrm{C}$ for $50 \mathrm{~s}$.

2.6. Immunofluorescence Analysis. Neuronally differentiated 46C ES cells for 15 days were fixed with $4 \%$ paraformaldehyde at room temperature for $20 \mathrm{~min}$ and then permeabilized for 20 min with permeabilization solution. Cells were incubated with anti-MapII (Chemicon) primary antibody for $1 \mathrm{~h}$. After washing 10 times with PBST (0.05\% Tween 20, $10 \mathrm{mM}$ $\mathrm{Na}_{2} \mathrm{HPO}_{4}, 2 \mathrm{mM} \mathrm{KH} \mathrm{PO}_{4}, 2.7 \mathrm{mM} \mathrm{KCl}$, and $137 \mathrm{mM} \mathrm{NaCl}$ ), cells were incubated with Alexa Fluor 488 (Invitrogen) and 
DAPI (KPL Inc) for $1 \mathrm{~h}$ in the dark to stain the nucleus, followed by washing again five times with PBST. Wells were mounted in a drop of Mount Medium (KPL Inc). Signal was visualized by fluorescence using a microscope (Leica DMIRB, Leica Microsystems).

2.7. Western Blot Analysis. Mouse ES cells were seeded in 6-well plates and differentiated in ES medium or N2B27 medium without LIF. mES cells were washed with phosphatebuffered saline (PBS) and then lysed in RIPA buffer $(25 \mathrm{mM}$ Tris- $\mathrm{HCl}$ at $\mathrm{pH} 8.0,150 \mathrm{mM} \mathrm{NaCl}, 10 \%$ glycerol, 1\% Igepal CA-630, 0.25\% deoxycholic acid, $2 \mathrm{mM}$ EDTA, $1 \mathrm{mM} \mathrm{NaF}$, and $50 \mathrm{mM}$ glycerophosphate) on ice for $30 \mathrm{~min}$. Lysates were cleared by centrifugation at $12,000 \mathrm{rpm}$ for $10 \mathrm{~min}$, after which supernatants were collected. Bradford (Bio-Rad) assay was used to determine the protein concentration. Equal amounts of protein were boiled and separated by SDS-polyacrylamide electrophoresis gels and transferred to a PVDF membrane (Pall Corporation). Blots were then incubated with antiactive- $\beta$-catenin (Millipore) or anti $\beta$-actin (Santa Cruz Biotechnology) antibody. Immunocomplexes were visualized using an enhanced Chemiluminescence kit (Elpis Biotech).

2.8. Chromatin Immunoprecipitation (ChIP) Assay. Cells were cross-linked with $1 \%$ formaldehyde (Sigma) at room temperature for $10 \mathrm{~min}$ and then incubated with $0.125 \mathrm{M}$ glycine for $5 \mathrm{~min}$ with gentle shaking. Cells were then washed twice with PBS before harvesting. Cells resuspended with hypotonic buffer (10 mM Hepes-KOH, pH 7.8, $10 \mathrm{mM} \mathrm{KCl,}$ and $1.5 \mathrm{mM} \mathrm{MgCl}_{2}$ ) were swollen on ice for $10 \mathrm{~min}$ and then passed through a 26.5 gauge needle six times. After centrifugation at top speed for $5 \mathrm{~min}$ at $4^{\circ} \mathrm{C}$, pellets were incubated with nuclei lysis buffer ( $1 \%$ SDS, $50 \mathrm{mM}$ Tris$\mathrm{HCl}, \mathrm{pH} 8.0$, and $10 \mathrm{mM}$ EDTA) for $10 \mathrm{~min}$ on ice with occasional vortexing. Chromatin was sheared to an average length size of $0.2 \sim 1 \mathrm{~kb}$ by sonication on ice. Supernatant was collected by centrifugation $\left(13,000 \mathrm{rpm}, 10 \mathrm{~min}, 4^{\circ} \mathrm{C}\right)$, and the supernatant concentration was determined by a spectrophotometer. The appropriate volume of chromatin was diluted 1:10 in ChIP dilution buffer (0.01\% SDS, $20 \mathrm{mM}$ Tris- $\mathrm{HCl}, \mathrm{pH} 8.0,167 \mathrm{mM} \mathrm{NaCl}, 1.2 \mathrm{mM}$ EDTA, and $1.1 \%$ Triton X-100), after which preclearing was performed at $4^{\circ} \mathrm{C}$ for $2 \mathrm{~h}$ with $10 \mu \mathrm{L}$ of protein $\mathrm{A} / \mathrm{G}$ plus-agarose beads (Santa Cruz Biotechnology). For immunoprecipitation, goat, rabbit-IgG (Bethyl), anti $\beta$-catenin (BD biosciences), antiTCF3 (Santa Cruz), and anti-TCF1 (cell signaling) antibodies were administered at $4^{\circ} \mathrm{C}$ overnight. Immunoprecipitated chromatins were eluted, after which reverse cross-linking was carried out by addition of $0.3 \mathrm{M} \mathrm{NaCl}$ at $65^{\circ} \mathrm{C}$ overnight. Following phenol-chloroform extraction and ethanol precipitation, DNA was dissolved in $50 \mu \mathrm{L}$ of TE buffer (10 mM Tris- $\mathrm{HCl}, \mathrm{pH}$ 8.0, and $1 \mathrm{mM}$ EDTA). Soxl-1 primers (Forward: 5' -AGTTCAGCCCTGAGTGAC-3' and Reverse: $5^{\prime}$-TGGGTGCCTAGCGGAGAG- $3^{\prime}$ ), Soxl-2 primers (Forward: $5^{\prime}$-TGGTCTGATCCCAAGTAG- $3^{\prime}$ and Reverse: $5^{\prime}$ TTTCTGAAGCGATTCTCC- $3^{\prime}$ ), and Axin primers (Forward: $5^{\prime}$-TAACGCGGGAGCTGAGTGTG-3' ${ }^{\prime}$ and Reverse: $5^{\prime}$-AAATCCATCGCGAACGGCTG-3') were used for PCR.

\section{Results}

3.1. Increase in Wnt/ $\beta$-Catenin Signaling Activity during Neural Differentiation. To study the role of Wnt signaling during neural differentiation, we used 46C mouse embryonic stem (ES) cells (EGFP was substituted into the ORF of the Sox1 gene) with the monolayer neural differentiation method. Upon being cultured in N2B27 medium, 46C ES cells started to express EGFP from day 4, and outgrowth of neurites was detected from day 8 after replating (Figures $1(\mathrm{a})-1(\mathrm{e}))$ [5]. To examine the expression patterns of Wnt components during differentiation, we performed RTPCR analysis using specific primers. RT-PCR data showed reduced expression of stemness markers (Oct4 and Nanog) and increased expression of an ectoderm marker (Sox1) during neuronal differentiation. Expression levels of many Wnts, Wnt receptors, Wnt coreceptors, and Wnts components also changed during differentiation (Figure 1(f)). These data suggest that Wnt signaling might play important roles in self-renewal or neuronal differentiation, although its exact functions are unknown.

Next, we asked whether Wnt signaling activity can be regulated under self-renewal and differentiation conditions. To this end, we measured endogenous Wnt/ $\beta$-catenin signaling activity under self-renewal and differentiation conditions using TOP and Wnt target genes Axin2 promoters (hereafter called Ax2P)-driven reporter construct that contain responsive TCF binding elements [26, 27]. Notably, reporter activities were low in undifferentiated mouse ES cells, whereas it was increased under absence of LIF conditions (Figure 2(a)). To monitor the change status of Wnt signaling during neural differentiation, we established reporter ES cell lines (Oct4Gip/TOP or Ax2P-mCherry). As expected, we observed only GFP expression but not mCherry expression in self-renewal condition due to low Wnt activity (Figure 2(d)). As shown in Figure 2(e), addition of BIO, GSK3 $\beta$ inhibitor, enhanced expression of mCherry, indicating that this cell line reflects Wnt $/ \beta$-catenin signaling. After stable cells were cultured in N2B27 medium for neural differentiation, expression of mCherry was significantly increased in neural precursor cells, whereas it was decreased in fully differentiated neurons (Figures 2(f)-2(g)). Consistently, the active $\beta$-catenin was more abundant during differentiation induced by the removal of LIF or N2B27 medium, which induces embryonic stem cells differentiation toward neuronal lineage, reaching a maximum on day 4 (Figure 2(b)). LRP6 phosphorylation on S1490, used an indicator for initial activation of Wnt/ $\beta$ catenin signaling, was increased during neural differentiation (Figure 2(c)). Taken together, these data suggest that Wnt/ $\beta$ catenin signaling is regulated during ES cell differentiation and neural precursor differentiation.

\subsection{Treatment of BIO from Days 4 to 6 Enhances Neural} Differentiation. Based on data described above (Figures 1 and 2 ), we asked whether time window of Wnt/ $\beta$-catenin signaling affects neural differentiation. For this, we sequentially treated with BIO (GSK3 $\beta$ inhibitor) for indicated duration as described in Figure 3 [24]. Addition of BIO in 46C ES cells from day 0 to day 6 completely diminished EGFP expression 


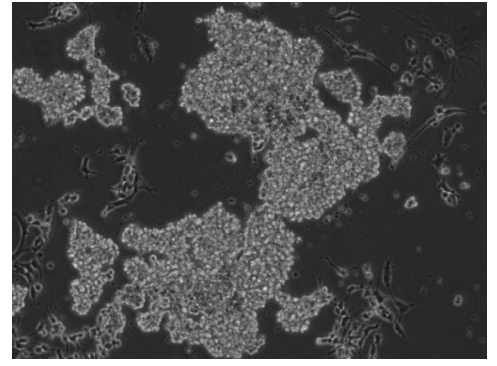

(a)

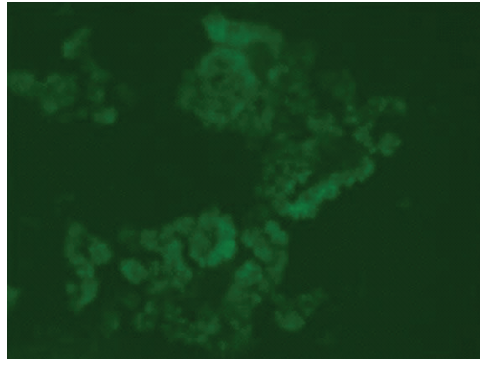

(b)

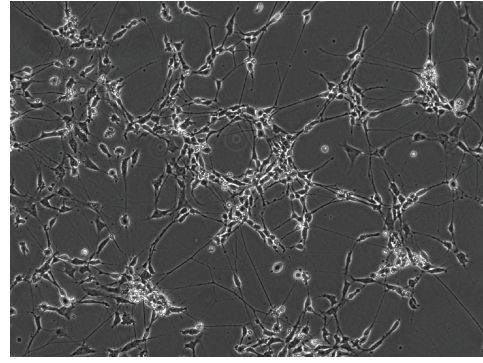

(c)

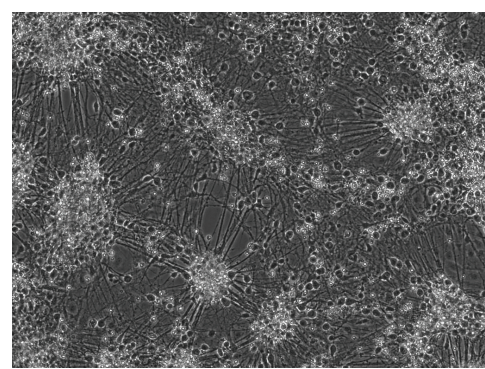

(d)

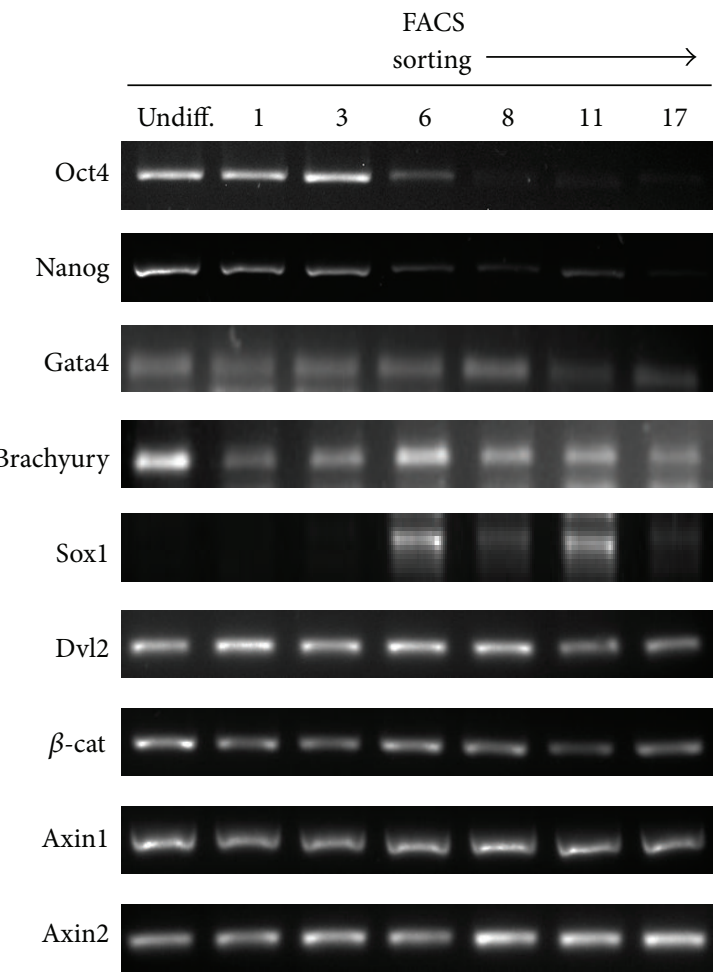

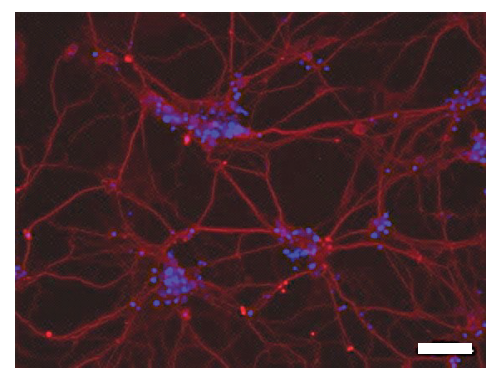

(e)

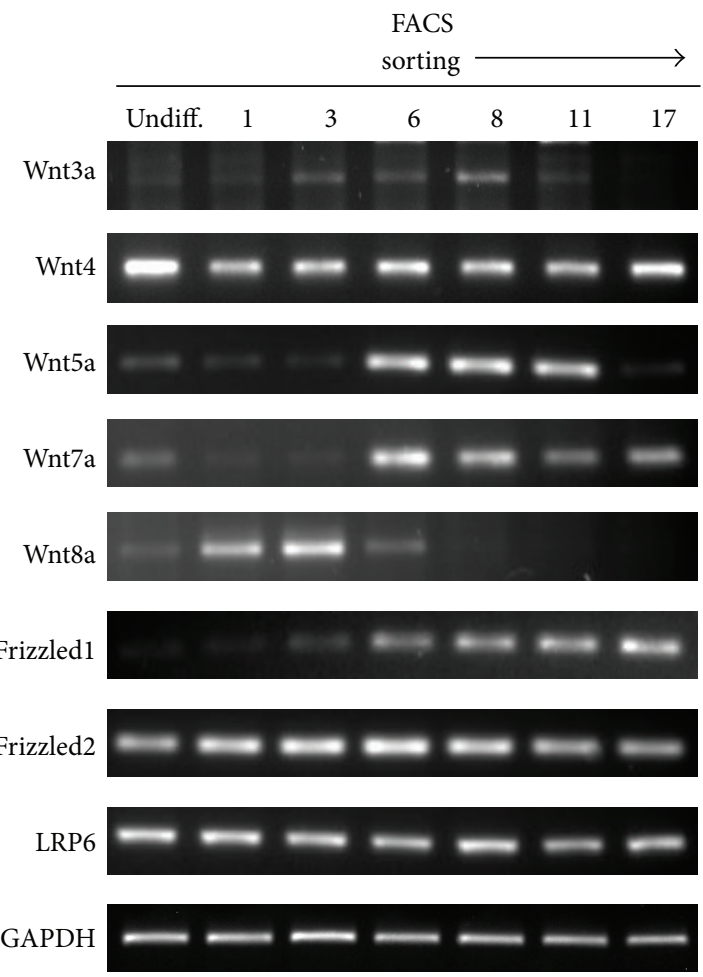

(f)

Figure 1: Neuronal differentiation of mouse embryonic stem cells and expression of Wnt and Wnt component genes. (a)-(e) Using N2B27 medium, 46C ES cells (Sox1-promoter-GFP) were differentiated to neuronal cells for 14 days. GFP in 46C ES cells was expressed during neuronal differentiation for 6 days ((a) phase contrast, (b) Soxl-GFP), and neurite outgrowth increased during neuronal differentiation for 8 days (c) and 14 days ((d) phase contrast, (e) MAPII (red), DAPI (blue)). (f) RT-PCR results of stem cell marker, Wnt, and Wnt signaling components during neuronal differentiation. During neuronal differentiation, RNA levels of many Wnt and Wnt signaling components were changed. Scale bars, $50 \mu \mathrm{m}$. 


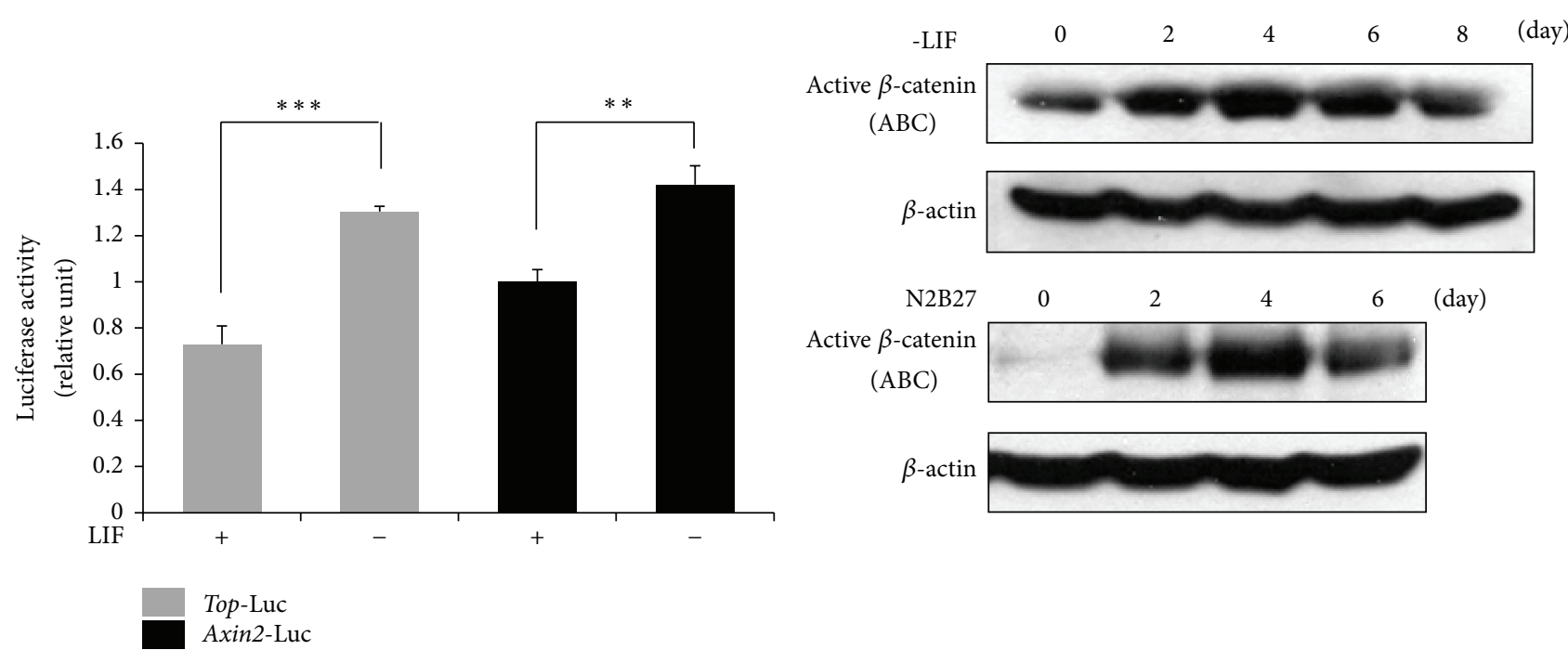

(a)

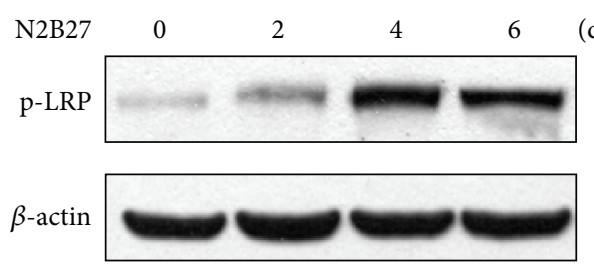

(c)
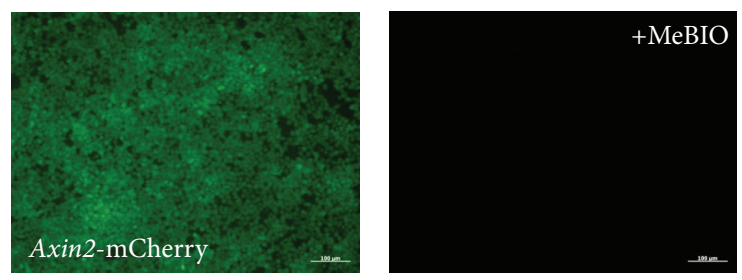

(d)
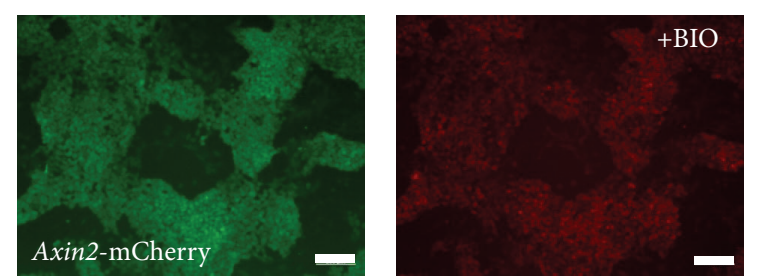

(e)
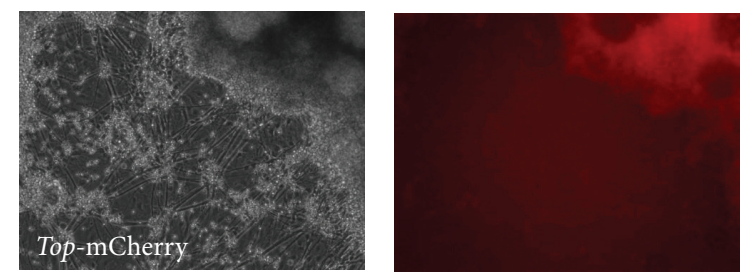

(f)
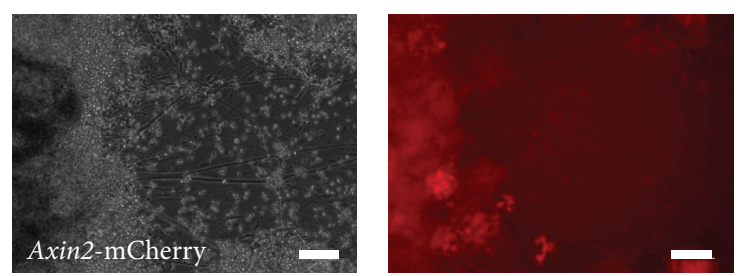

(g)

FIGURE 2: Increase in canonical Wnt signaling during neural differentiation. (a) Both TOP and Axin2 promoter luciferase activities in E14 ES cells were induced at $48 \mathrm{~h}$ after LIF removal. (b) Western blot analysis using ABC (active $\beta$-catenin) and $\beta$-actin antibodies. Active $\beta$-catenin level was the highest on day 4 of neural differentiation. (c) p-LRP level was the highest on day 4 of neural differentiation. (d)-(e) In Oct4Gip/Ax2P-mCherry cells, only GFP expression was detected. mCherry expression was increased after $24 \mathrm{~h}$ addition of BIO (0.75 $\mu \mathrm{M})$. (f)-(g) mCherry expression increased in the neural precursor region of TOP-mCherry ((d) and (e)) and Ax2p-mCherry ((f) and (g)) stable cell lines during neuronal differentiation. Stable cell lines were cultured in N2B27 medium for 14 days. Scale bars, $100 \mu \mathrm{m}$.

compared to MeBIO treatment, a control analog of BIO which displays minimal activity against GSK3 $\beta$ (Figures $3(a)$ and $3(\mathrm{~b})$ ). These results were corroborated by FACS analysis (Figures $3(\mathrm{~g})$ and $3(\mathrm{~h})$ ). Similar to report that activation of canonical Wnt signaling by GSK3 $\beta$ inhibition maintains pluripotency of ES cell, we found that BIO treatment could enhance the expression of stemness marker gene such as Nanog under differentiation conditions (Figure 3(i)) [18$20,28]$. On the other hand, treatment with BIO from day 4 to day 6 surprisingly increased EGFP intensity and EGFPpositive cells (Figures 3(f)-3(h)). To test whether or not the increase in EGFP expression by BIO can be attributed 


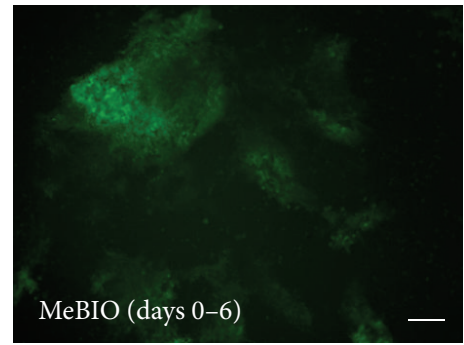

(a)

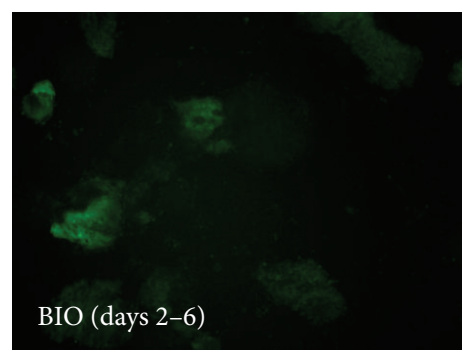

(d)

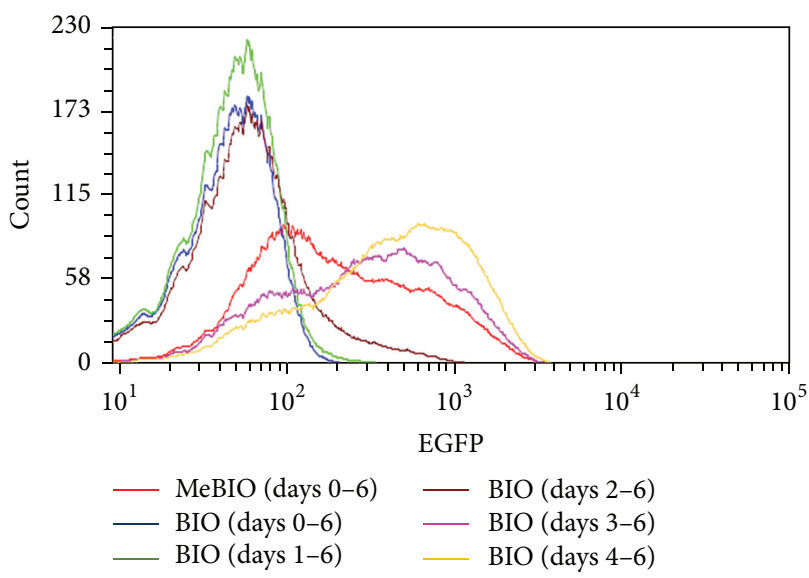

(g)

(b)

(e)
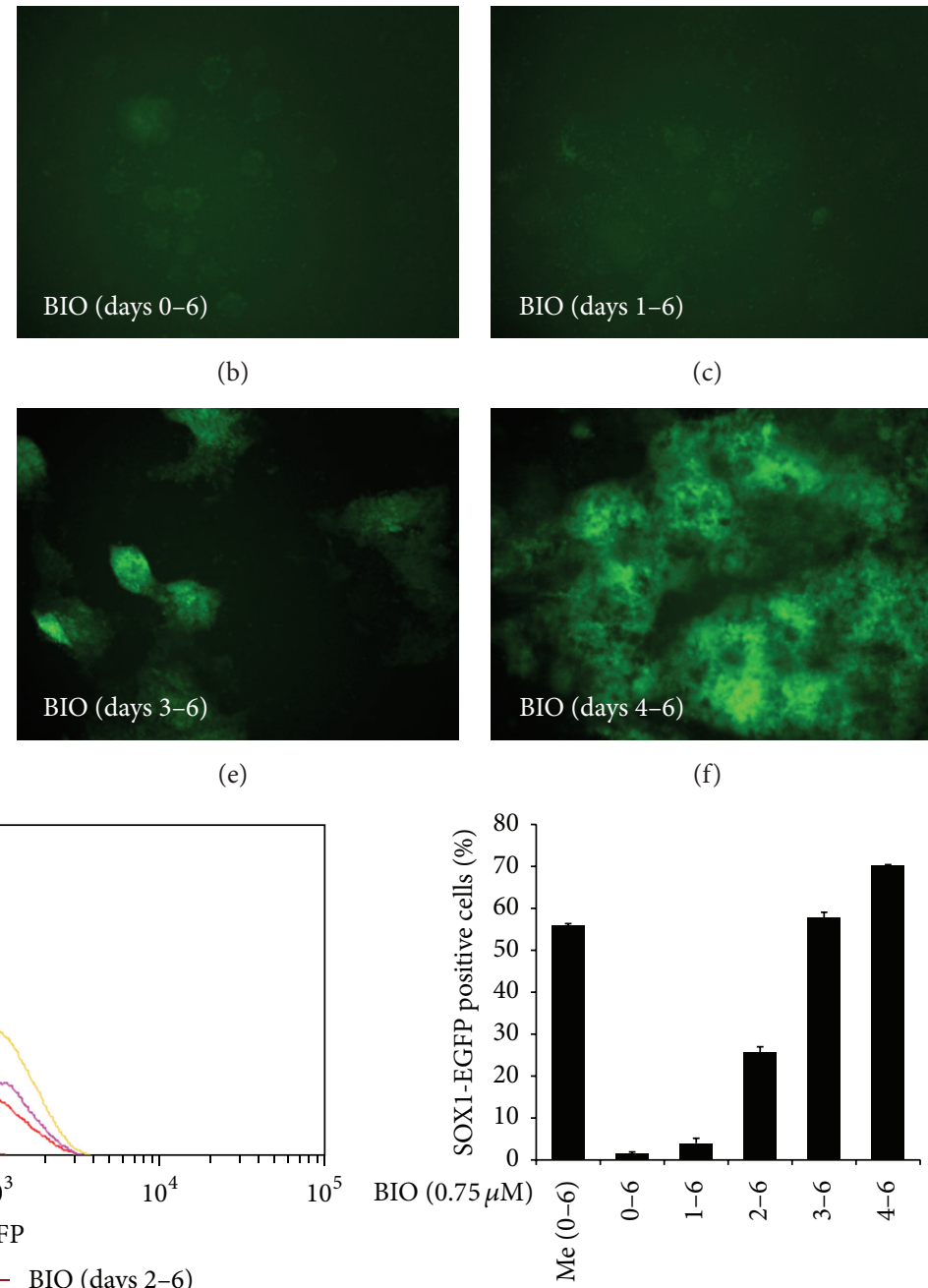

(h)

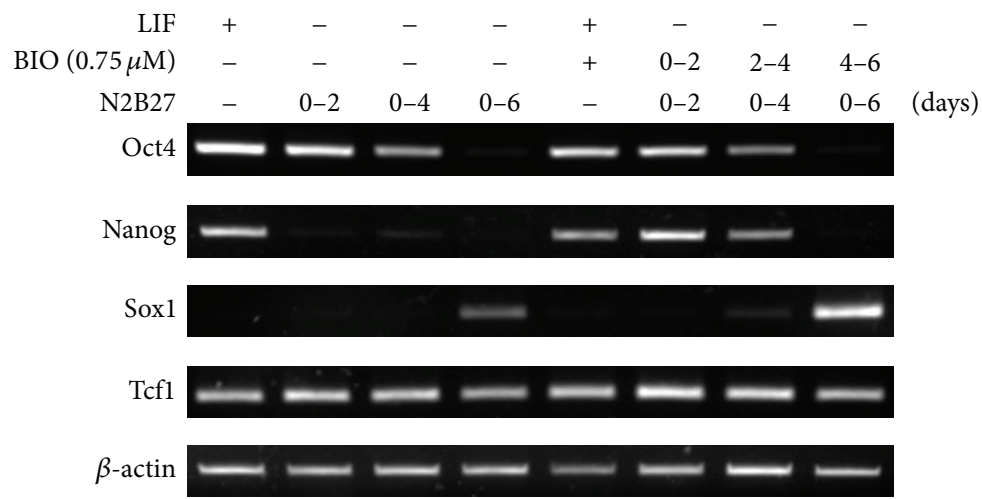

(i)

FIGURE 3: Increase in neural differentiation of precursor cells by GSK3 $\beta$ inhibitor (BIO) during days 4 to 6 in N2B27 medium. (a)-(f) $46 \mathrm{C}$ ES cells were cultured in N2B27 medium for 6 days. GFP expression was elevated by BIO treatment $(0.75 \mu \mathrm{M})$ from days 4 to 6 , whereas GFP expression was reduced by BIO treatment $(0.75 \mu \mathrm{M})$ from days 0 to 3. (g) FACS analysis of Sox1-GFP expression during monolayer differentiation in N2B27 medium. (h) Proportions of Sox1-GFP expressing cells as determined by FACS. (i) RT-PCR analysis showed that Nanog and Soxl expression were elevated by BIO treatment $(0.75 \mu \mathrm{M})$ under nondifferentiation and neural differentiation conditions, respectively. Scale bars, $100 \mu \mathrm{m}$. 


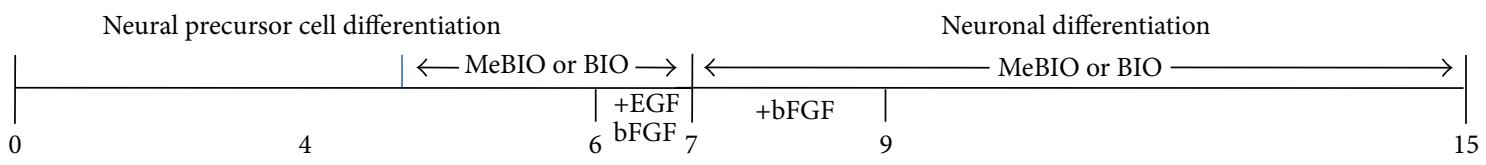

(day)

(a)

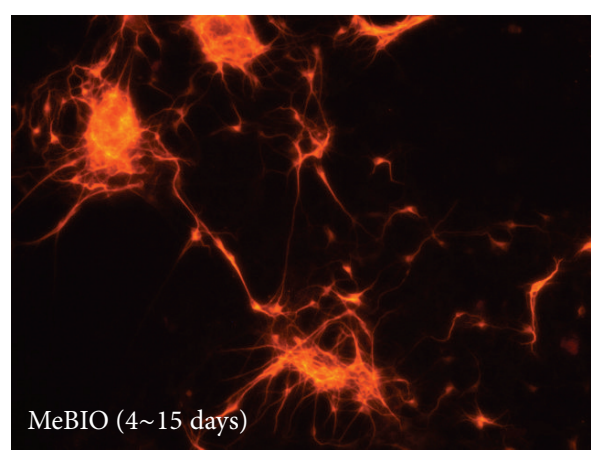

(b)

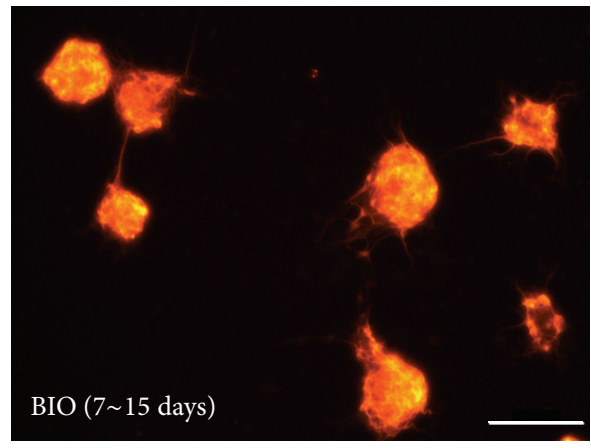

(d)

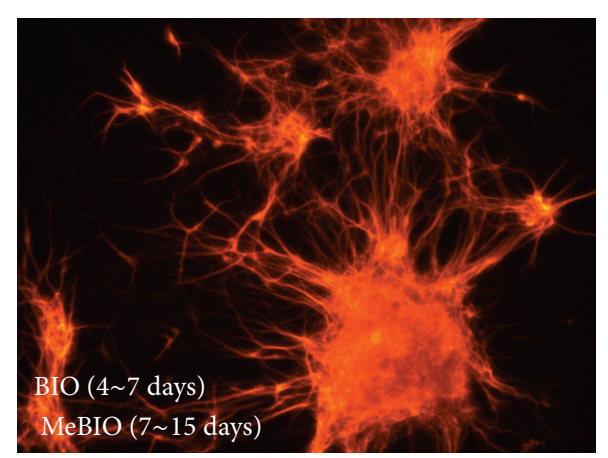

(c)

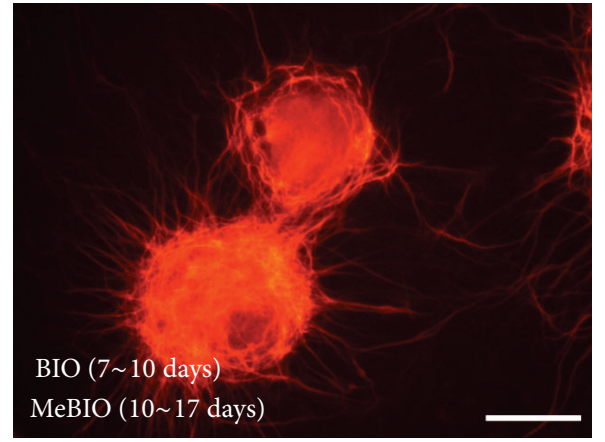

(e)

FIGURE 4: Inhibition of neurite formation during late neuronal differentiation by GSK3 $\beta$ inhibitor. (a) Diagram of MeBIO ( $0.75 \mu \mathrm{M})$ or $\mathrm{BIO}(0.75 \mu \mathrm{M})$ treatment during late neuronal differentiation of $46 \mathrm{C}$ ES cells. (b)-(e) Cells cultured according to the diagram for 15 days were stained with MAPII antibody. Neurite formation was elevated by BIO treatment from days 4 to 7 (c), whereas it was reduced by BIO treatment from days 4 to 15 (d). (e) Cells were cultured with BIO from days 7 to 10 and cultured with MeBIO for 7 days after replating, followed by staining with MAPII antibody. Scale bars, $100 \mu \mathrm{m}$.

to actual neural differentiation, we compared the mRNA expression levels of marker genes in cells treated or untreated with BIO. We observed that the expression Sox1 mRNA was increased in ES cells after BIO treatment from day 4 compared to untreated cells (Figure 3(i)). These results imply that activation of $\mathrm{Wnt} / \beta$-catenin signaling for different time periods has differential effects on neural differentiation of mES cells.

\subsection{Transient Activation of Wnt/ $\beta$-Catenin Signaling Enhances} Neuronal Differentiation. The finding that the activation of Wnt signaling differentially regulates neuronal differentiation of ES cells promotes us to define the optimal condition for neuronal differentiation. To this end, we treated with $\mathrm{Me}$ $\mathrm{BIO}$ or BIO from 4 to 7 days during neural differentiation, followed by treatment again with $\mathrm{Me}-\mathrm{BIO}$ or $\mathrm{BIO}$ from 8 to 15 days after replating on PDL-laminin-coated plates (Figure 4(a)). Neurite formation induced by BIO from days 4 to 7 was remarkably enhanced compared to MeBIO treatment (Figures 4(b) and 4(c)). In contrast, neurite formation was completely abolished by BIO treatment from days 7 to 15 (Figure 4(d)). Next, we checked whether or not neurite formation derived from precursor cells could be recovered by withdrawing of BIO during neuronal differentiation. We treated with BIO into precursor cells for 3 days after replating, and then cells were cultured in the absence of BIO for 7 days more during neuronal differentiation. Interestingly, neurite formation of Map2-positive cells was restored under BIOdeficient conditions (Figure 4(e)). These data indicate that transient activation of Wnt/ $\beta$-catenin signaling during neural precursor formation may be beneficial for optimal neuronal differentiation.

3.4. IWR-1-Endo Treatment from Days 4 to 6 Suppresses Differentiation of Neural Precursor Cells. As GSK3 $\beta$ has been known to be involved in multiple signaling pathways in addition to Wnt/ $\beta$-catenin signaling, we elucidated neural differentiation efficiency by using a specific inhibitor IWR1-endo (Axin stabilizer) $[25,29]$. Similar to data shown in Figure 3, neural differentiation of ES cells was reduced by 


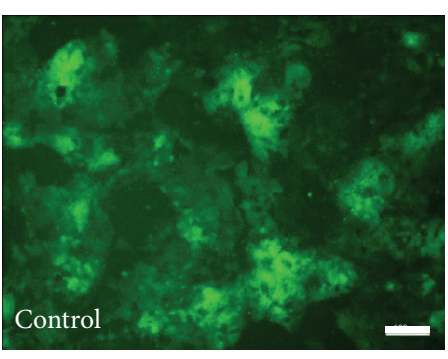

(a)

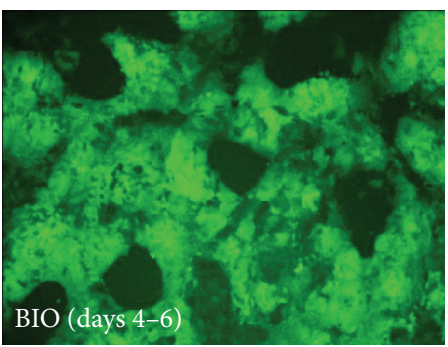

(d)

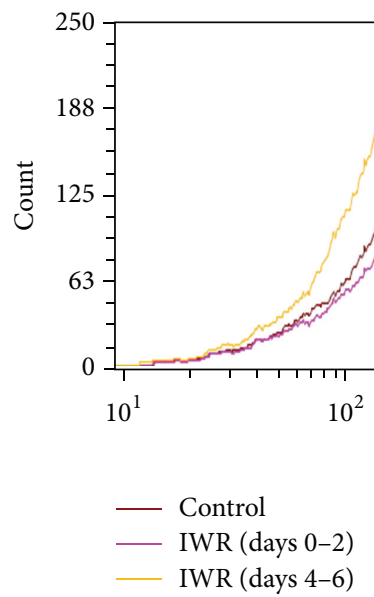

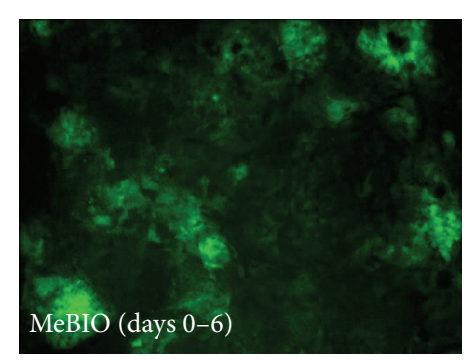

(b)

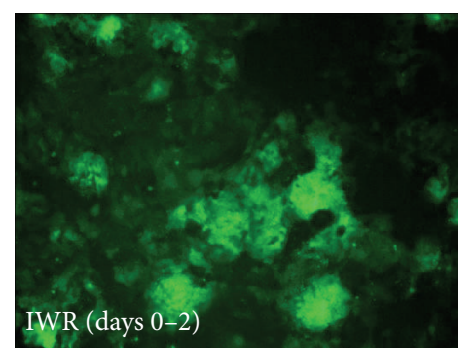

(e)

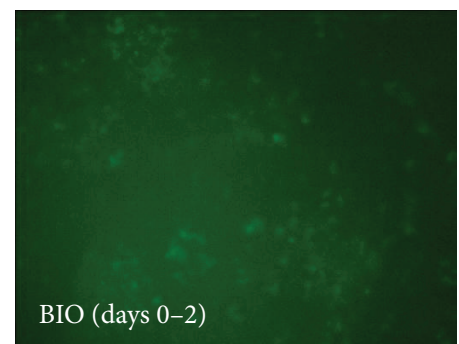

(c)

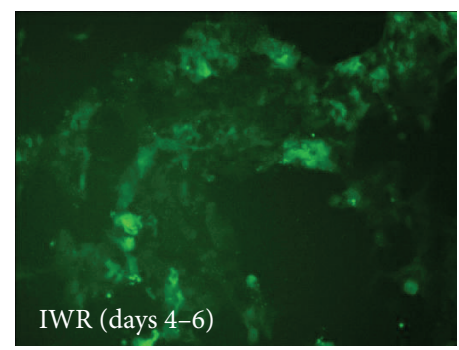

(f)

(h)

FIGURE 5: Decrease in neural differentiation of precursor cells by an Axin stabilizer (IWR-1-endo) from days 4 to 6 in N2B27 medium. (a)-(f) GFP expression of $46 \mathrm{C}$ cells was elevated by BIO treatment $(0.75 \mu \mathrm{M})$ from days 4 to 6 , whereas it was reduced by IWR-1-endo $(0.75 \mu \mathrm{M})$ treatment from days 4 to 6 . Cells were cultured in N2B27 medium for 6 days. (g) FACS analysis of Sox1-GFP expression during monolayer differentiation in N2B27 medium. (h) Proportions of Soxl-GFP expressing cells as determined by FACS. Scale bars, $100 \mu \mathrm{m}$.

treatment with $\mathrm{BIO}$ from days 0 to 2 , whereas it was increased from days 4 to 6 (Figures $5(\mathrm{a})-5(\mathrm{~d})$ ). On the contrary, treatment of 46C ES cells with IWR-1-endo from day 4 to day 6 resulted in a significant reduction in neural differentiation, whereas Wnt signaling inhibition by IWR-1-endo from days 0 to 2 caused a slight increase in differentiation (Figures 5(e), 5(f), and 5(h)). These results were further corroborated by FACS analysis of EGFP expression (Figures 5(g) and 5(h)). Based on these data, we conclude that activation of $\mathrm{Wnt} / \beta$ catenin signaling on days 4 to 6 is essential for the proper formation of neural precursor cells.

3.5. The Expression of Sox1 Is Enhanced by Direct Binding of $\beta$-Catenin-TCF1 to the Promoter during Neural Differentiation. We found that BIO enhances Soxl mRNA expression during neural differentiation (Figure 3(i)). Therefore, we then examined whether $\beta$-catenin directly could be occupied at promoter of Soxl gene during neural differentiation. Interestingly, several conserved putative TCF/LEF-binding sites were present in a $3 \mathrm{~kb}$ promoter region of both human and mouse Sox1 gene (Figure 6(a)). In order to verify this hypothesis that the complex of $\beta$-catenin and TCF/LEF transcription factors could bind to these conserved binding sites, we carried out chromatin immunoprecipitation (ChIP) analysis using antibodies specific for $\beta$-catenin, TCF1, and TCF3. Notably, $\beta$-catenin and TCF1 did not access to Soxl-1 and Soxl- 2 region under nondifferentiation and early differentiation conditions, whereas they associated with all three potential binding sites from day 4 during monolayer differentiation. In addition, we found weak binding of $\beta$-catenin and TCF1 to Sox1-3 


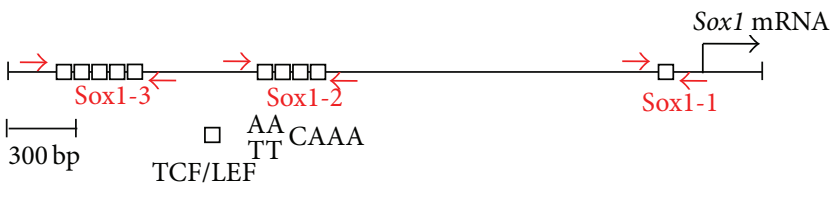

(a)

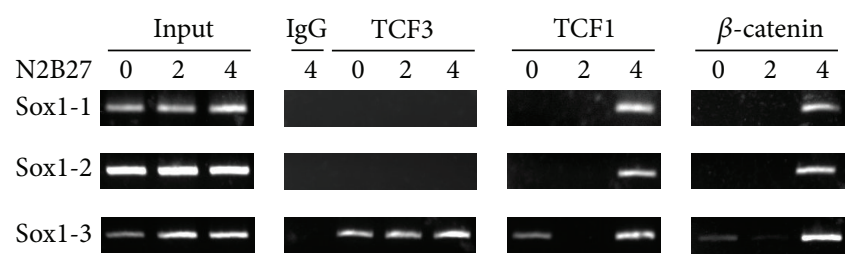

(b)

FIGURE 6: Increased Wnt/ $\beta$-catenin signaling directly regulates Soxl promoter activity during neural differentiation. (a) Schematic representation of binding sites for TCF/LEF transcription factors in a $3 \mathrm{~kb}$ promoter region of the Soxl gene. Three pairs of PCR primers were designed based on potential TCF/LEF binding sites. (b) ChIP analysis of the mouse Sox1 promoter with $\beta$-catenin, TCF1, or TCF3 antibodies. $\beta$-catenin and TCF1 bound to the Sox1 promoter from day 4 during neural differentiation.

region in self-renewal stem cells. This weak $\beta$-catenin-TCF1 binding on Soxl-3 at day 0 may have a rheostatic role in transcriptionally controlling expression of Soxl gene during differentiation. Soxl-3 region is a distal control element located around $3 \mathrm{~kb}$ from the transcription initiation site. Therefore, we expect that weak interaction of $\beta$-cateninTCF1 keeps a ready state to easily activate genes. On the other hand, TCF3 occupancy, a known repressor protein for Wnt signaling, was not changed during differentiation (Figure 6(b)). These data indicate that $\beta$-catenin/TCF1 complex activates Soxl promoter through direct binding to the conserved TCF binding sites during the late stage of neural precursor differentiation.

\section{Discussion}

Here we showed that the expression of various Wnt signaling components is dynamically changed during neuronal differentiation (Figure 1), but the biological meaning of these changes and regulation of the expression of these genes are largely unknown. However, overall Wnt $/ \beta$-catenin signaling activity in undifferentiated ES cells seems to be low compared to differentiated stage (Figure 2). Although it has been shown that activation of $\mathrm{Wnt} / \beta$-catenin signaling by the treatment of BIO or Wnt3a enhances stemness of ES cells $[18,19,30]$, these findings are not contradictory to our findings. Our data suggest that an increase of Wnt $/ \beta$-catenin signaling is necessary (Figure 5) but not sufficient to induce neuronal differentiation of ES cells. It may be possible that increase of $\mathrm{Wnt} / \beta$-catenin signaling than endogenous level in undifferentiated state is sufficient to enhance stemness, but other unknown changes during differentiation along with high level of Wnt/ $\beta$-catenin signaling may be required for proper neuronal differentiation of ES cells.

Tsao et al. [31] showed that Soxl acts as a tumor suppressor by inhibiting TCF-responsive transcriptional activity in hepatocellular carcinoma. Interestingly, our ChIP analysis showed that $\beta$-catenin-TCF complex could regulate the expression of Soxl in the middle of neuronal differentiation periods (Figure 6). Although further study would be necessary to test the possibility, increase of Wnt $/ \beta$-catenin signaling induced Soxl until generation of neural precursors and then increased level of Soxl suppresses Wnt/ $\beta$-catenin signaling during late neuronal differentiation period.
We identified that treatment of $\mathrm{BIO}$ at specific time points during differentiation can enhance neuronal differentiation (Figure 3). Treatment of BIO from the beginning of differentiation as well as continuous activation of $\mathrm{Wnt} / \beta$-catenin signaling until late neuronal differentiation stage blocked neuronal differentiation, which might be due to enhancing self-renewal of ES cells and inhibitory effect of Wnt $/ \beta$-catenin signaling on late neuronal differentiation period, respectively, as shown before $[18,19,23]$. Our findings could be useful information in therapeutic point of view using stem cells, since the treatment of $\mathrm{Wnt} / \beta$-catenin signaling activator along with small molecules regulating other signaling pathways will further enhance neuronal differentiation.

\section{Conflict of Interests}

The authors declare that there is no conflict of interests regarding the publication of this paper.

\section{Acknowledgments}

This work was supported by the grants from the National Research Foundation to E. Jho (2011-0019353 and 2012M3A9C6050109) and the California Institute for Regenerative Medicine (CIRM) New Faculty Award II (RN200938-1) and the CIRM Scientific Excellence through Exploration and Development (SEED) Grant (RS1-00327-1) to Q.-L. Ying.

\section{References}

[1] G. Keller, "Embryonic stem cell differentiation: emergence of a new era in biology and medicine," Genes and Development, vol. 19, no. 10, pp. 1129-1155, 2005.

[2] A. G. Smith, "Embryo-derived stem cells:of mice and men," Annual Review of Cell and Developmental Biology, vol. 17, pp. 435-462, 2001.

[3] P. P. L. Tam, M. Kanai-Azuma, and Y. Kanai, "Early endoderm development in vertebrates: lineage differentiation and morphogenetic function," Current Opinion in Genetics and Development, vol. 13, no. 4, pp. 393-400, 2003.

[4] G. Bain, D. Kitchens, M. Yao, J. E. Huettner, and D. I. Gottlieb, "Embryonic stem cells express neuronal properties in vitro," Developmental Biology, vol. 168, no. 2, pp. 342-357, 1995. 
[5] Q.-L. Ying and A. G. Smith, "Defined conditions for neural commitment and differentiation," Methods in Enzymology, vol. 365, pp. 327-341, 2003.

[6] Q. L. Ying, M. Stavridis, D. Griffiths, M. Li, and A. Smith, "Conversion of embryonic stem cells into neuroectodermal precursors in adherent monoculture," Nature Biotechnology, vol. 21, no. 2, pp. 183-186, 2003.

[7] W. Kim, M. Kim, and E.-H. Jho, "Wnt/beta-catenin signalling: from plasma membrane to nucleus," Biochemical Journal, vol. 450, no. 1, pp. 9-21, 2013.

[8] A. Wodarz and R. Nusse, "Mechanisms of Wnt signaling in development," Annual Review of Cell and Developmental Biology, vol. 14, pp. 59-88, 1998.

[9] J. R. Miller, A. M. Hocking, J. D. Brown, and R. T. Moon, "Mechanism and function of signal transduction by the Wnt/betacatenin and Wnt/Ca ${ }^{2+}$ pathways," Oncogene, vol. 18 , no. 55 , pp. 7860-7872, 1999.

[10] J. H. van Es, N. Barker, and H. Clevers, "You Wnt some, you lose some: oncogenes in the Wnt signaling pathway," Current Opinion in Genetics and Development, vol. 13, no. 1, pp. 28-33, 2003.

[11] J. Behrens, J. P. von Kries, M. Kühl et al., "Functional interaction of $\beta$-catenin with the transcription factor LEF-1," Nature, vol. 382, no. 6592, pp. 638-642, 1996.

[12] M. Molenaar, M. van de Wetering, M. Oosterwegel et al., "XTcf-3 transcription factor mediates $\beta$-catenin-induced axis formation in xenopus embryos," Cell, vol. 86, no. 3, pp. 391-399, 1996.

[13] C. Mosimann, G. Hausmann, and K. Basler, "Beta-catenin hits chromatin: regulation of Wnt target gene activation," Nature Reviews Molecular Cell Biology, vol. 10, no. 4, pp. 276-286, 2009.

[14] M. Kléber and L. Sommer, "Wnt signaling and the regulation of stem cell function," Current Opinion in Cell Biology, vol. 16, no. 6, pp. 681-687, 2004.

[15] H. Niwa, "Wnt: what's needed to maintain pluripotency?" Nature Cell Biology, vol. 13, no. 9, pp. 1024-1026, 2011.

[16] R. Nusse, "Wnt signaling and stem cell control," Cell Research, vol. 18, no. 5, pp. 523-527, 2008.

[17] S. Y. Sokol, "Maintaining embryonic stem cell pluripotency with Wnt signaling," Development, vol. 138, no. 20, pp. 4341-4350, 2011.

[18] J. Hao, T.-G. Li, X. Qi, D.-F. Zhao, and G.-Q. Zhao, "WNT/ $\beta$ catenin pathway up-regulates Stat 3 and converges on LIF to prevent differentiation of mouse embryonic stem cells," Developmental Biology, vol. 290, no. 1, pp. 81-91, 2006.

[19] N. Sato, L. Meijer, L. Skaltsounis, P. Greengard, and A. H. Brivanlou, "Maintenance of pluripotency in human and mouse embryonic stem cells through activation of Wnt signaling by a pharmacological GSK-3-specific inhibitor," Nature Medicine, vol. 10, no. 1, pp. 55-63, 2004.

[20] L. Pereira, F. Yi, and B. J. Merrill, "Repression of Nanog gene transcription by Tcf3 limits embryonic stem cell self-renewal," Molecular and Cellular Biology, vol. 26, no. 20, pp. 7479-7491, 2006.

[21] G. Dravid, Z. Ye, H. Hammond et al., "Defining the role of Wnt $/ \beta$-catenin signaling in the survival, proliferation, and selfrenewal of human embryonic stem cells," Stem Cells, vol. 23, no. 10, pp. 1489-1501, 2005.

[22] J. J. Otero, W. Fu, L. Kan, A. E. Cuadra, and J. A. Kessler, " $\beta$-catenin signaling is required for neural differentiation of embryonic stem cells," Development, vol. 131, no. 15, pp. 35453557, 2004.
[23] J. Aubert, H. Dunstan, I. Chambers, and A. Smith, "Functional gene screening in embryonic stem cells implicates Wnt antagonism in neural differentiation," Nature Biotechnology, vol. 20, no. 12, pp. 1240-1245, 2002.

[24] L. Meijer, A. L. Skaltsounis, P. Magiatis et al., "GSK-3-selective inhibitors derived from Tyrian purple indirubins," Chemistry \& Biology, vol. 10, no. 12, pp. 1255-1266, 2003.

[25] B. Chen, M. E. Dodge, W. Tang et al., "Small molecule-mediated disruption of Wnt-dependent signaling in tissue regeneration and cancer," Nature Chemical Biology, vol. 5, no. 2, pp. 100-107, 2009.

[26] E.-H. Jho, T. Zhang, C. Domon, C.-K. Joo, J.-N. Freund, and F. Costantini, "Wnt/ $\beta$-catenin/Tcf signaling induces the transcription of Axin2, a negative regulator of the signaling pathway," Molecular and Cellular Biology, vol. 22, no. 4, pp.1172$1183,2002$.

[27] M. van de Wetering, R. Cavallo, D. Dooijes et al., "Armadillo coactivates transcription driven by the product of the Drosophila segment polarity gene dTCF,' Cell, vol. 88, no. 6, pp. 789-799, 1997.

[28] K. F. Kelly, D. Y. Ng, G. Jayakumaran, G. A. Wood, H. Koide, and B. W. Doble, " $\beta$-catenin enhances Oct- 4 activity and reinforces pluripotency through a TCF-independent mechanism," Cell Stem Cell, vol. 8, no. 2, pp. 214-227, 2011.

[29] B. W. Doble and J. R. Woodgett, "GSK-3: tricks of the trade for a multi-tasking kinase," Journal of Cell Science, vol. 116, no. 7, pp. 1175-1186, 2003.

[30] Q.-L. Ying, J. Wray, J. Nichols et al., "The ground state of embryonic stem cell self-renewal," Nature, vol. 453, no. 7194, pp. 519-523, 2008.

[31] C.-M. Tsao, M.-D. Yan, Y.-L. Shih et al., "SOX1 functions as a tumor suppressor by antagonizing the $\mathrm{WNT} / \beta$-catenin signaling pathway in hepatocellular carcinoma," Hepatology, vol. 56, no. 6, pp. 2277-2287, 2012. 

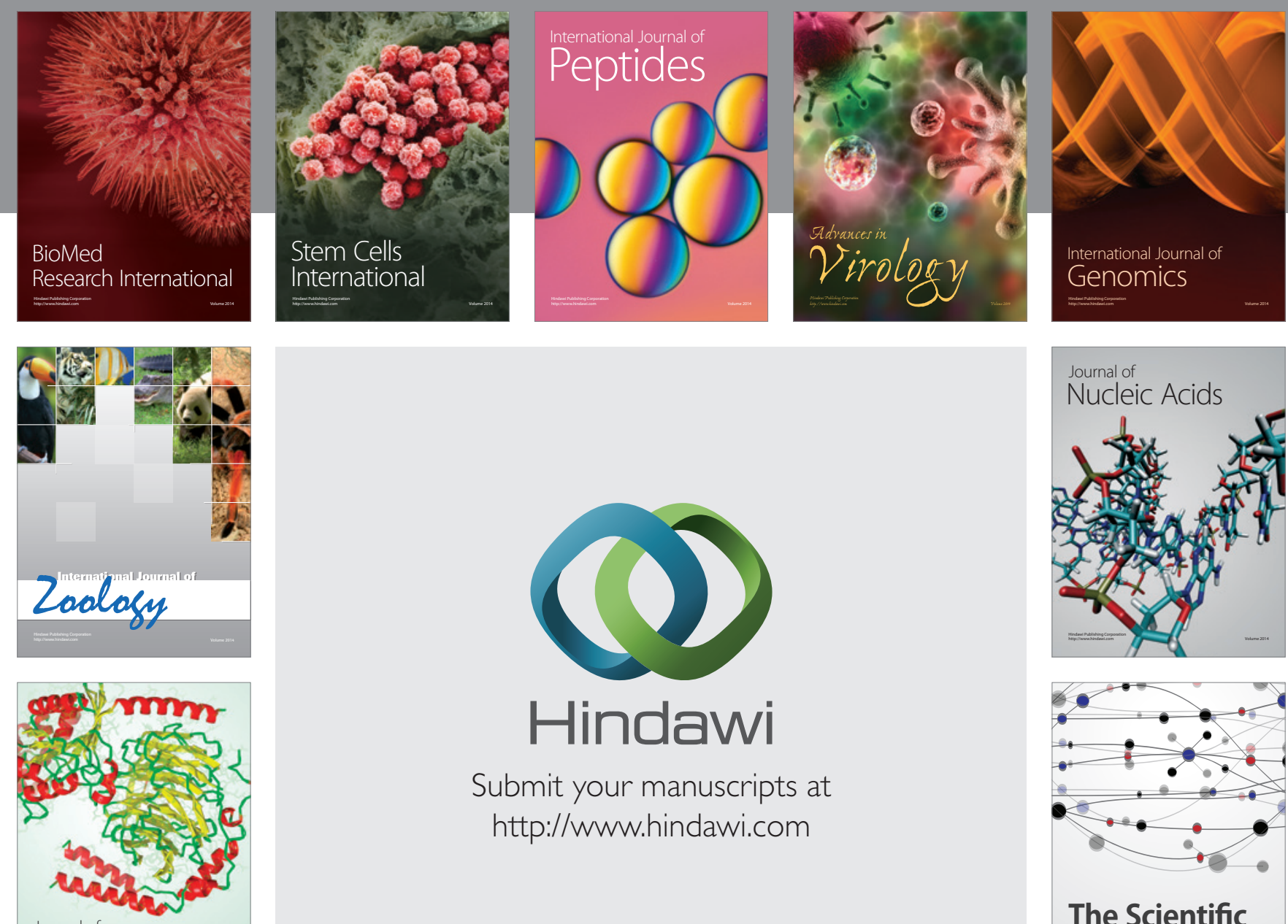

Submit your manuscripts at

http://www.hindawi.com

Journal of
Signal Transduction
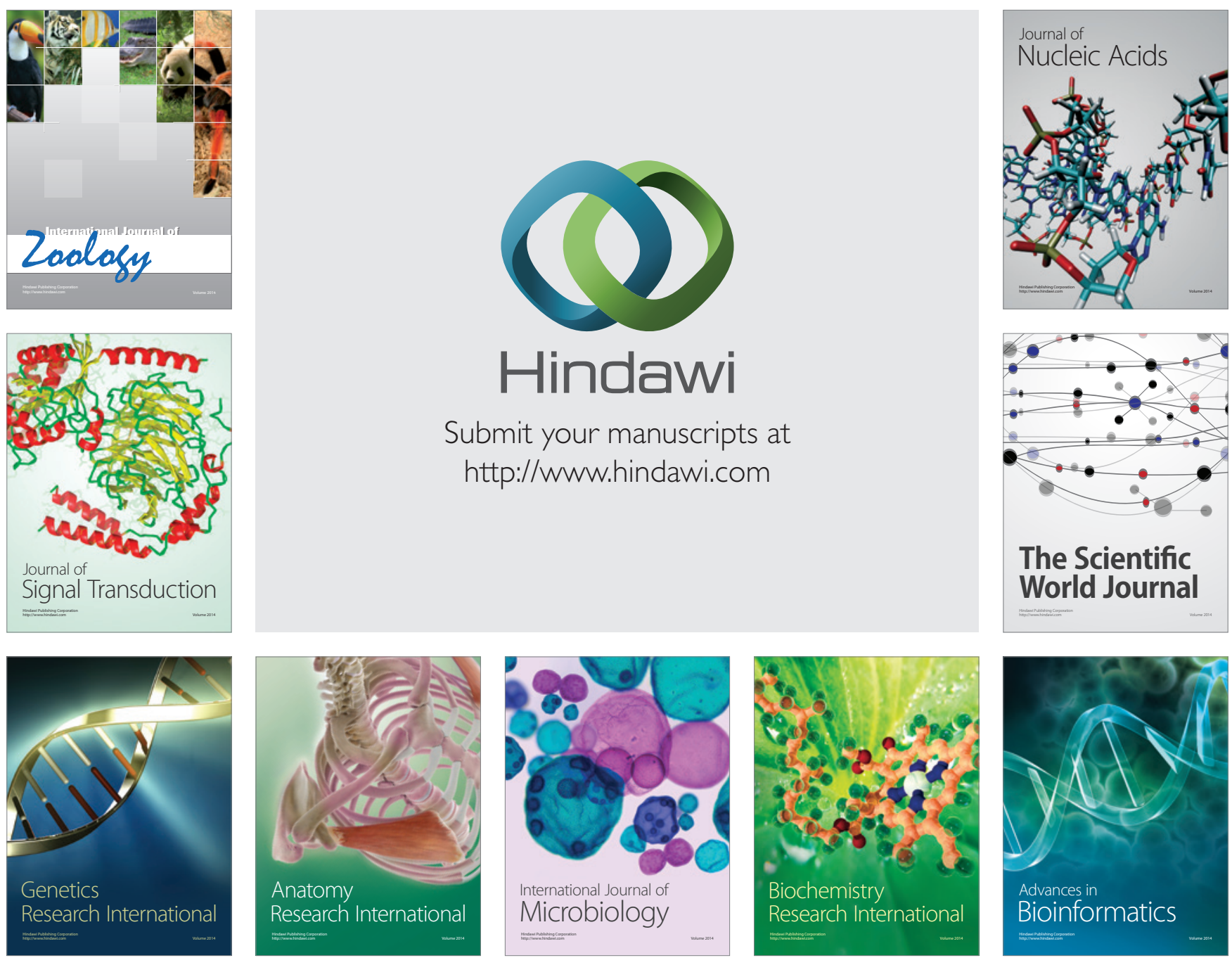

The Scientific World Journal
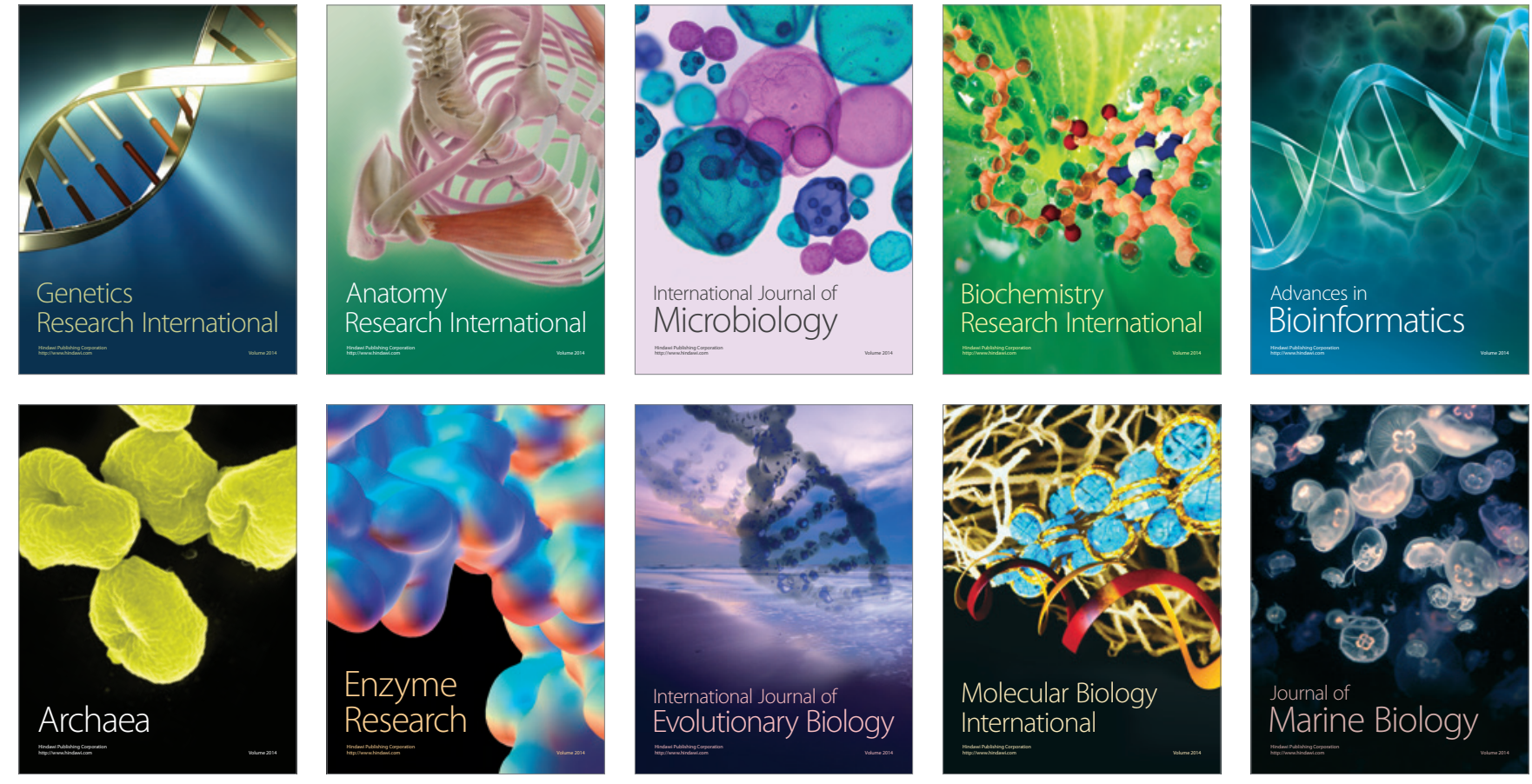